\title{
FITOREMEDIASI MERKURI (Hg) MENGGUNAKAN TANAMAN KACANG KALOPO (Calopogonium mucunoides)
}

\author{
Y.S. Samar' ${ }^{1}$ A. Mariwy ${ }^{*}$, J. B. Manuhutu ${ }^{1}$ \\ ${ }^{1}$ Departement of Chemistry-FKIP, Pattimura University Ambon \\ *Corresponding author: A. Mariwy \\ abrahammariwy@gmail.com
}

\begin{abstract}
Phytoremediation of mercury $(\mathrm{Hg})$ is one of the remediation methods by utilizing accumulator plants to reduce mercury $(\mathrm{Hg})$ heavy metal pollutans in polluted soil. This study aims to determine the level of accumulation of heavy metal mercury $(\mathrm{Hg})$ by the calopo bean plant (Calopogonium mucunoides) based on the value of Bioconcentration Factor (BCF) and Translocation Factor (TF) and the variation of contact time between plants and soil contaminated with mercury between 40 to 50 days. The sample testing using the mercury analyzer instrument equipped with EDL (Electrodeless Low-Pressure Mercury Lamp) light sources at wavelength of 253,7 $\mathrm{nm}$. The results showed that the highest mercury uptake was found at the remediation time of 50 days with a root absorption concentration of $0,7538 \mathrm{ppm}$ and at leaves of $0,0476 \mathrm{ppm}$. Calculation results show that the value of the Bioconcentration Factor (BCF) was 6,7458 and the Translocation factor value was 0,0631 . Thus the calopo bean plant was categorized as an accumulator plant because the value of $\mathrm{BCF}>1$ and could be used as one of phytoremediator plants for mercury $(\mathrm{Hg})$ contaminated soil but in the phytostabilization mechanism because the value of $\mathrm{TF}<1$.
\end{abstract}

Keywords: Phytoremediation, Mercury, Calopogonium mucunoides, Phytostabilization

\begin{abstract}
ABSTRAK. Fitoremediasi merkuri (Hg) merupakan salah satu metode remediasi dengan memanfaatkan tumbuhan akumulator untuk mengurangi bahan pencemar logam berat merkuri $(\mathrm{Hg})$ dalam tanah tercemar. Penelitian ini bertujuan untuk mengetahui besarnya tingkat akumulasi logam berat merkuri $(\mathrm{Hg})$ oleh tanaman kacang kalopo (Calopogonium mucunoides) berdasarkan nilai Faktor Biokonsentrasi (BCF) dan Faktor Translokasi (TF), dan variasi waktu kontak antara tanaman dengan tanah tercemar antara 40 dan 50 hari. Pengujian sampel menggunakan instrumen Merkuri Analyzer yang dilengkapi dengan sumber cahaya EDL (Electrodeless Low-Pressure Mercury Lamp) pada panjang gelombang 253,7 nm. Hasil penelitian menunjukkan bahwa serapan merkuri $(\mathrm{Hg})$ tertinggi terdapat pada waktu remediasi 50 hari dengan konsentrasi penyerapan pada akar sebesar $0,7538 \mathrm{ppm}$ dan pada daun sebesar 0,0476 ppm. Hasil perhitungan menunjukkan bahwa nilai Faktor Biokonsentrasi (BCF) sebesar 6,7458 dan nilai Faktor Translokasi (TF) sebesar 0,0631. Dengan demikian maka tanaman kacang kalopo (Calopogonium mucunoides) dikategorikan sebagai tanaman akumulator karena niali $\mathrm{BCF}>1$ dan dapat digunakan sebagai salah satu tanaman fitoremediator terhadap tanah tercemar merkuri $(\mathrm{Hg})$, namun dalam mekanisme fitostabilisasi karena nilai $\mathrm{TF}<1$.
\end{abstract}

Kata kunci : Fitoremediasi, Merkuri, Calopogonium mucunoides, Fitostabilisasi

\section{Pendahuluan}

Eksploitasi sumber daya alam seperti industri pertambangan adalah suatu kegiatan tak terelakkan untuk memenuhi kebutuhan ekonomi, sumber keuangan negara, dan lain-lain. Namun setiap eksploitasi sumber daya alam ini akan memberikan dampak terhadap lingkungan, budaya dan sosial baik positif maupun negatif. Industri pertambangan merupakan salah satu industri yang berdampak pada kerusakan lingkungan baik lingkungan fisik maupun sosial karena pada umumnya industri pertambangan menghasilkan limbah yang cukup besar (Tindaon, 2012). 
Pencemaran tanah merupakan salah satu masalah yang timbul dari pembuangan limbah logam berat (Tindaon, 2012), karena tanah merupakan media yang mempunyai fungsi baik sebagai media tempat berdirinya tanaman maupun sebagai gudang hara yang dibutuhkan tanaman (Arsyad dkk., 2011). Tindakan pemulihan tanah perlu dilakukan agar tanah yang tercemar dapat digunakan kembali dengan aman. Metode yang digunakan dalam menanggulangi pencemaran yang terjadi adalah penerapan metode bioremediasi di atas permukaan tanah dan di dalam tanah. Bioremediasi dapat dilakukan dengan pola fitoremediasi (Juhria, 2016).

Fitoremediasi adalah penggunaan tumbuhan untuk menghilangkan polutan dari tanah atau perairan yang terkontaminasi. Akhir-akhir ini teknik reklamasi dengan fitoremediasi mengalami perkembangan yang sangat pesat. Dengan berkembangnya teknologi fitoremediasi maka tumbuhan hiperakumulator logam menjadi sangat penting. Tanaman hiperakumulator mampu mengakumulasi logam dengan konsentrasi lebih dari 100 kali melebihi tanaman normal, dimana tanaman normal mengalami keracunan logam dan penurunan produksi. Hal ini terjadi karena adanya perbedaan serangkaian proses fisiologis dan biokimiawi serta ekspresi gen-gen yang mengendalikan penyerapan, akumulasi dan toleransi tanaman terhadap logam (Hidayati dkk., 2013).

Berdasarkan penelitian yang dilakukan oleh Hidayati dkk., (2006), hasil analisis dengan metode Atomic Absorption Spectrometry (AAS) menunjukkan bahwa tanaman kacang kalopo (Calopogonium mucunoides) terbukti menyerap logam $\mathrm{Hg}$ sebesar 0,6800 ppm. Sedangkan Juhaeti dkk., (2005) dengan metode yang sama yaitu Atomic Absorption Spectrometry (AAS), melaporkan bahwa tanaman kacang kalopo (Calopogonium mucunoides) mampu menyerap logam $\mathrm{Pb}$ sebesar 6,16 ppm dan sianida sebesar 3,35 ppm. Arsyad dkk., (2011) juga melaporkan bahwa tanaman kacang kalopo (Calopogonium mucunoides) dapat memperbaiki sifat fisika tanah melalui peningkatan bahan organik, serta meningkatkan ketersediaan air tanah.

Tanaman kacang kalopo dapat dimanfaatkan sebagai tanaman fitoremediator karena tanaman ini dapat tumbuh dengan cepat pada semua tekstur tanah dan tahan terhadap kekeringan dengan suhu mencapai $36^{\circ} \mathrm{C}$, cara tumbuhnya yaitu membelit membuat sehingga tanaman ini mampu beradaptasi baik pada beragam kondisi ekologi serta mampu merehabilitasi lahan yang terdegradasi, selain itu tanaman ini tidak dimanfaatkan sebagai sumber pangan sehingga berpotensi baik sebagai tanaman fitoremediator (Litbang Departemen Pertanian, 2010). Pada penelitian ini tanaman kacang kalopo (Calopogonium mucunoides) akan dimanfaatkan sebagai agen fitoremediasi terhadap tanah tercemar logam berat merkuri $(\mathrm{Hg})$.

\section{Metode}

Penelitian ini dilakukan pada bulan Agustus sampai Nopember tahun 2018. Bahan yang digunakan dalam penelitian ini adalah tanaman kacang kalopo (Calopogonium mucunoides) serta tanah tercemar logam berat merkuri (Hg). Tanaman dibiarkan tumbuh dalam media tanam dan dipanen untuk dianalisis kadar logam berat merkuri $(\mathrm{Hg})$ dengan variasi waktu kontak tiap 10 hari setelah ditanam selama 30 hari yaitu pada hari ke-40 dan 50. Preparasi sampel dan analisis merkuri $(\mathrm{Hg})$ dilakukan di Laboratorium LPPT-UGM. Pengujian sampel menggunakan instrumen Merkuri Analyzer yang dilengkapi dengan sumber cahaya EDL (Electrodeless LowPressure Mercury Lamp) pada panjang gelombang 253,7 nm.

\section{Cara Kerja}

\section{1) Penyiapan Media Tanam}

Sampel tanah yang diambil, dipisahkan dari sampah-sampah yang masih bercampur kemudian dimasukkan masing-masing $4 \mathrm{~kg}$ ke dalam 3 buah wadah tanpa lubang dan diberi nomor 1, 2, dan 3 . Selanjutnya pada wadah nomor 2 dan 3 disirami dengan $300 \mathrm{~mL}$ larutan merkuri 10 ppm, dan dibiarkan hingga mengering selama 1 hari, tanah tersebut diaduk secara merata dan dibiarkan selama 1 minggu sehingga menghasilkan tanah yang tercemar merkuri (Irsyad dkk., 2014).

\section{2) Penyiapan Bibit dan Penanaman Bibit}

Penyiapan dan penanaman tanaman kacang kalopo (Calopogonium mucunoides) diawali dengan proses penyemaian bibit yang ditanam pada tanah yang bebas merkuri, setelah bibit berumur 3 minggu dipilih tanaman dengan penampilan fenotip hampir sama (akar, batang dan daunnya). Masing-masing wadah yang telah diisi dengan media tanam, ditanami dengan 4 individu tanaman kacang kalopo (Calopogonium mucunoides), dan dibiarkan tumbuh selama 30 hari. 


\section{3) Pemanenan Tanaman Kacang Kalopo (Calopogonium mucunoides)}

Pemanenan dilakukan pada waktu remediasi 10 hari dan 20 hari. Tanaman yang sudah dipanen kemudian dicuci menggunakan air dan dibersihkan kembali dengan akuades hingga bersih. Dipisahkan daun, dan akar dari tanaman kacang kalopo (Calopogonium mucunoides).

\section{4) Destruksi sampel akar dan daun.}

Sampel akar dan daun ditimbang masing-masing \pm 1 gram kemudian dimasukan ke dalam erlenmeyer $100 \mathrm{~mL}$ dan ditambahkan $10 \mathrm{~mL} \mathrm{HNO}_{3}: \mathrm{HClO}_{4}(1: 1)$ setelah itu dipanaskan hingga jernih dan keluar asap putih, campuran kemudian disaring dan ditepatkan dengan akuades dalam labu takar $50 \mathrm{~mL}$, larutan kemudian siap dibaca serapannya menggunakan mercury analyzer (LPPT-UGM, 2018).

\section{5) Destruksi Sampel Tanah.}

Sampel media tanam (tanah) diambil dari masing-masing wadah pada saat pemanenan tanaman setelah itu, sampel tanah ditimbang \pm 1 gram kemudian dimasukan ke dalam erlenmeyer $100 \mathrm{~mL}$ dan ditambahkan $5 \mathrm{~mL}$ $\mathrm{H}_{2} \mathrm{SO}_{4}$ kemudian ditambahkan lagi $5 \mathrm{~mL} \mathrm{HNO}_{3}: \mathrm{HClO}_{4}(1: 1)$ setelah itu dipanaskan hingga jernih dan keluar asap putih, campuran kemudian disaring dan ditepatkan dengan akuades dalam labu takar $50 \mathrm{~mL}$, larutan kemudian siap dibaca serapannya menggunakan mercury analyzer (LPPT-UGM, 2018).

\section{6) Analisis Sampel}

Larutan sampel akar, daun, dan tanah masing-masing dipipet $10 \mathrm{~mL}$ dan dimasukan ke dalam tabung reaksi dan ditambahkan berturut-turut $0,1 \mathrm{~mL} \mathrm{KMnO}_{4} 0,1 \% ; 0,1 \mathrm{~mL} \mathrm{HONH}{ }_{3} \mathrm{Cl} 10 \%$ dan $0,5 \mathrm{~mL}$ larutan $\mathrm{SnCl}_{2} \mathrm{dan}$ dihomogenkan, selanjutnya larutan dibaca serapannya menggunakan mercury analyzer (LPPT-UGM, 2018).

\section{Hasil Penelitian}

\section{Proses Fitoremediasi Tanaman Kacang Kalopo (Calopogonium mucunoides)}

Fitoremediasi merupakan salah satu metode remediasi dengan mengandalkan peranan tumbuhan untuk menyerap, mendegradasi, mentransformasi, dan mengimobilisasi bahan pencemar logam berat. Fitoremediasi dalam penelitian ini dilakukan selama 40 dan 50 hari. Penentuan waktu fitoremediasi ini didasarkan pada beberapa alasan di antaranya, untuk melihat pengaruh waktu fitoremediasi terhadap serapan logam berat merkuri $(\mathrm{Hg})$ oleh tanaman kacang kalopo. Tanaman dibiarkan tumbuh selama 30 hari dalam media tanam dan akan dipanen setiap 10 hari sebanyak dua kali yaitu pada hari ke-40 dan hari ke-50. Selain itu, dalam rentang waktu yang telah ditentukan, diperkirakan bahwa tanaman kacang kalopo telah tumbuh secara maksimal dan telah beradaptasi dengan tanah tercemar logam berat sehingga proses penyerapan logam berat merkuri $(\mathrm{Hg})$ dapat terjadi dengan baik. Selama proses remediasi berlangsung, reaktor-reaktor ini diletakan dalam rumah kaca sederhana seperti yang ditunjukkan pada Gambar 1.

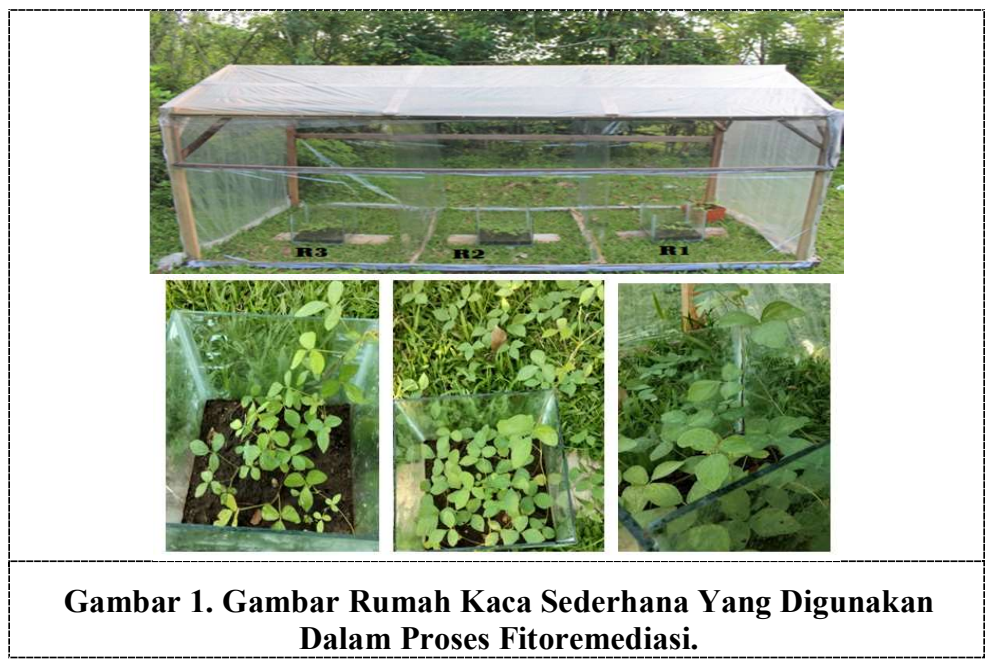


Gambar 1 menunjukkan kondisi tanaman saat proses fitoremediasi dilakukan dalam rumah kaca sederhana. Tujuan penggunaan rumah kaca agar tanaman terhindar dari cahaya matahari secara langsung. Selain itu rumah kaca juga berfungsi untuk mencegah masuknya hama yang dapat merusak tanaman. Untuk menjaga ketersediaan air dalam tanah, dilakukan penyiraman terhadap masing-masing reaktor dengan air yang cukup. Penyiraman dilakukan sampai pada saat pemanenan tanaman sesuai dengan jangka waktu yang telah ditetapkan.

\section{Kandungan Logam Berat Merkuri (Hg) dalam Tanaman Kacang Kalopo (Calopogonium Mucunoides)}

Tabel 1. Kandungan Logam Berat Merkuri (Hg) dalam Sampel Akar dan Daun Tanaman Kacang Kalopo (Calopogonium mucunoides) serta Media Tanam.

\begin{tabular}{ccccc}
\hline Reaktor & Kode Sampel & $\begin{array}{c}\text { Waktu Kontak } \\
\text { (Hari) }\end{array}$ & Absorbansi & Kandungan (mg/kg) \\
\hline \multirow{2}{*}{1} & $\mathrm{~T}_{0}$ & 0 & 0,0306 & 1,4200 \\
& $\mathrm{~T}_{1}$ & 50 & 0,0257 & 0,0702 \\
& $\mathrm{~A}_{1}$ & 50 & 0,0187 & 0,0478 \\
\hline 2 & $\mathrm{D}_{1}$ & 50 & 0.0419 & 0,1140 \\
\hline 3 & $\mathrm{~T}_{2}$ & 40 & 0.0409 & 1,9284 \\
& $\mathrm{~A}_{2}$ & 40 & 0,0132 & 0,0247 \\
& $\mathrm{D}_{2}$ & 40 & 0,0070 & 0,0087 \\
\hline & $\mathrm{T}_{3}$ & 50 & 0,0421 & 0,7538 \\
& $\mathrm{~A}_{3}$ & 50 & 0,0147 & 0,0476 \\
\hline
\end{tabular}

Keterangan: $\mathrm{T}_{0}$ : tanah sebelum fitoremediasi; $\mathrm{T}_{1}, \mathrm{D}_{1}, \mathrm{~A}_{1}$ : tanaman kontrol, $\mathrm{T}_{2}, \mathrm{~A}_{2}, \mathrm{D}_{2}$ : tanaman panen pertama; $\mathrm{T}_{3}, \mathrm{~A}_{3}, \mathrm{D}_{3}$ : tanaman panen kedua.

Berdasarkan Tabel 1 dapat dilihat bahwa pada reaktor pertama kandungan merkuri dalam tanah adalah sebesar $0,0702 \mathrm{mg} / \mathrm{kg}$ sedangkan kandungan merkuri pada akar dan daun berturut-turut adalah $0,0478 \mathrm{mg} / \mathrm{kg}$ dan $0,1140 \mathrm{mg} / \mathrm{kg}$. Kandungan logam berat dalam media tanam relatif kecil karena pada reaktor pertama ini berfungsi sebagai kontrol dimana tidak dicemari dengan merkuri $(\mathrm{Hg})$, namun demikian pada sampel media tanam (tanah) terdapat logam berat merkuri $(\mathrm{Hg})$ sebesar $0,0702 \mathrm{mg} / \mathrm{kg}$. Hal ini disebabkan karena merkuri $(\mathrm{Hg}) \mathrm{merupakan}$ salah satu unsur yang terdistribusi pada lapisan kerak bumi dengan kelimpahan rata-rata 0,08 mg/kg (Larkin, (2005) dalam Khalifah, 2007). Karena keberadaannya di alam secara alami menyebabkan sehingga bagian akar tanaman dapat menyerap logam berat merkuri $(\mathrm{Hg})$ dalam tanah dan mentranslokasikannya ke bagian daun. Selain itu, kandungan logam berat merkuri $(\mathrm{Hg})$ dalam daun pada reaktor pertama ini cenderung lebih besar karena logam berat merkuri dapat terakumulasi di daun melalui translokasi dari akar yang mengabsorpsi logam merkuri $(\mathrm{Hg})$ dari tanah yang tercemar. Hal ini sejalan dengan pernyataan Soemirat (2003) bahwa proses absorpsi dapat terjadi lewat beberapa organ tumbuhan seperti akar, daun, dan stomata. Tumbuhan mempunyai kemampuan menyerap ion-ion logam dari lingkungannya ke dalam tubuh melalui membran sel. Selain itu, ion $\mathrm{Hg}$ merupakan salah satu jenis ion logam yang mudah untuk ditranslokasikan ke tajuk tanaman. $\mathrm{Hg}^{2+}$ juga merupakan ion yang tepat untuk disimpan dalam tempat penyimpanan seperti vakuola sub seluler sel epidermal dengan kapasitas yang tinggi (Soemirat, 2003).

Pada reaktor kedua (40 hari) kandungan merkuri $(\mathrm{Hg})$ dalam tanah setelah dianalisis adalah sebesar 1,9284 $\mathrm{mg} / \mathrm{kg}$ sedangkan akar mampu menyerap logam berat merkuri $(\mathrm{Hg})$ sebesar 0,0247 mg/kg dan daun sebesar 0,0087 $\mathrm{mg} / \mathrm{kg}$. Kandungan logam berat merkuri yang diserap sangat kecil karena tanaman masih dalam masa pertumbuhan awal sehingga bahan pencemar yang dalam hal ini adalah merkuri $(\mathrm{Hg})$ masih terendapkan di tanah dan belum banyak diserap atau bahkan ditranslokasikan ke bagian tumbuhan yang lain seperti akar dan daun.

Bila dibandingkan kandungan merkuri $(\mathrm{Hg})$ dalam media tanam reaktor kedua lebih tinggi daripada kandungan merkuri awal dalam media tanam yaitu sebesar 1,4200 mg/kg. Peningkatan kandungan logam berat merkuri (Hg) dalam tanah terkontaminasi menunjukkan bahwa logam telah terendapkan dalam tanah. Kandungan logam berat merkuri dalam tanah disebabkan tanah terkontaminasi sudah cukup lama dan kandungan logam beratnya terus menerus bertambah, sehingga senyawa organik yang ada telah mengalami degradasi (Hardiani dkk., 2011). Selain itu, faktor yang juga turut mempengaruhi terjadinya peningkatan kandungan merkuri (Hg) dalam 
tanah pada reaktor kedua adalah kurangnya sirkulasi udara di dalam rumah kaca sehingga menyebabkan uap merkuri yang terbentuk dari proses penguapan tidak terlepas seluruhnya ke udara melainkan tetap berada di dalam rumah kaca dan pada akhirnya akan kembali terendapkan di tanah.

Pada reaktor ketiga setelah dilakukan fitoremediasi selama 50 hari, kandungan logam berat merkuri $(\mathrm{Hg})$ yang diserap oleh tanaman kacang kalopo (Calopogonium mucunoides) mengalami peningkatan yaitu pada akar, jumlah merkuri yang diserap adalah $0,7538 \mathrm{mg} / \mathrm{kg}$ (30 kali lebih besar daripada reaktor kedua). Arisusanti dan Purwani (2013) menyatakan bahwa pada saat menyerap logam berat, tanaman yang adaptif akan membentuk suatu enzim reduktase pada akar. Enzim reduktase tersebut berfungsi untuk mereduksi logam yang kemudian logam diangkut di dalam membran akar.

Pada reaktor ketiga terjadi peningkatan kandungan merkuri $(\mathrm{Hg})$ dalam daun tanaman kacang kalopo dari $0,0087 \mathrm{mg} / \mathrm{kg}$ (reaktor kedua) menjadi $0,0476 \mathrm{mg} / \mathrm{kg}$ (reaktor ketiga). Hal ini menunjukkan bahwa pada reaktor ketiga, kandungan merkuri $(\mathrm{Hg})$ dalam daun tanaman kacang kalopo meningkat 5 kali lebih besar daripada reaktor kedua. Hal ini disebabkan karena tanaman kacang kalopo berada dalam proses pertumbuhan sehingga proses penyerapan dan akumulasi merkuri masih berlangsung hingga tercapai kondisi optimum (jenuh) (Chussetijowati dkk., 2012). Selain itu, peningkatan kandungan logam berat merkuri (Hg) pada bagian tanaman kacang kalopo (akar dan daun) dipengaruhi oleh waktu remediasi. Semakin lama waktu remediasi maka konsentrasi logam berat yang diserap oleh tanaman akan semakin besar pula. Hal ini sejalan dengan pendapat Widyati (2011), bahwa umur tanaman dan lamanya waktu tanaman berada pada tanah tercemar sangat menentukan banyaknya serapan logam oleh tanaman tersebut.

Sementara itu, kandungan merkuri $(\mathrm{Hg})$ dalam tanah tercemar mengalami penurunan dari $1,4200 \mathrm{mg} / \mathrm{kg}$ (kandungan $\mathrm{Hg}$ sebelum fitoremediasi) menjadi $0,1188 \mathrm{mg} / \mathrm{kg}$ (kandungan $\mathrm{Hg}$ setelah fitoremediasi), artinya terjadi penurunan kandungan logam berat merkuri $(\mathrm{Hg})$ sebesar $91,6338 \%$. Hal ini menunjukkan bahwa tanaman kacang kalopo telah menyerap sebagian merkuri $(\mathrm{Hg})$ dalam tanah, disamping itu sebagian merkuri (Hg) juga terlepas ke udara melalui penguapan mengingat merkuri $(\mathrm{Hg})$ merupakan salah satu jenis logam berat yang mampu menguap ke atmosfer (Pivetz, 2001 dalam U.S EPA, 2007).

Tabel 2. Nilai Faktor Biokonsentrasi (BCF) dan Faktor Translokasi (TF) Tanaman Kacang Kalopo (Calopogonium mucunoides)

\begin{tabular}{|c|c|c|c|c|c|c|}
\hline \multirow{2}{*}{$\begin{array}{c}\text { Kadungan } \\
\text { Hg dalam } \\
\text { Tanah } \\
(\mathrm{mg} / \mathrm{kg})\end{array}$} & \multirow{2}{*}{$\begin{array}{c}\text { Kandungan } \\
\text { Hg dalam } \\
\text { Akar } \\
(\mathrm{mg} / \mathrm{kg})\end{array}$} & \multirow{2}{*}{$\begin{array}{c}\text { Kandungan } \\
\text { Hg dalam } \\
\text { Daun } \\
(\mathrm{mg} / \mathrm{kg})\end{array}$} & \multicolumn{2}{|c|}{ BCF } & \multirow{2}{*}{$\begin{array}{l}\text { BCF } \\
\text { Total }\end{array}$} & \multirow[t]{2}{*}{ TF } \\
\hline & & & Akar & Daun & & \\
\hline $0,0702 *$ & 0,0478 & 0,1140 & 0,6809 & 1,6239 & 2,3048 & 2,3849 \\
\hline $1,9284 * *$ & 0,0247 & 0,0087 & 0,0128 & 0,0045 & 0,0173 & 0,3515 \\
\hline $0,1188 * * *$ & 0,7538 & 0,0476 & 6,3451 & 0,4007 & 6,7458 & 0,0631 \\
\hline
\end{tabular}

Keterangan: *: Reaktor pertama; **: Reaktor kedua; ***: Reaktor ketiga

Tabel 2 menunjukkan nilai BCF dan TF tanaman Kacang Kalopo (Calopogonium mucunoides). Berdasarkan nilai Faktor Biokonsentrasi (BCF) dan Faktor Translokasi (TF) yang diperoleh dari hasil penelitian maka tanaman kacang kalopo (Calopogonium mucunoides) dikategorikan sebagai tanaman akumulator serta dapat digunakan sebagai salah satu tanaman fitoremediator terhadap tanah tercemar logam berat merkuri $(\mathrm{Hg})$ namun dalam mekanisme fitostabilisasi dengan minimal waktu remediasi selama 50 hari.

\section{Kesimpulan}

Berdasarkan penelitian yang telah dilakukan, maka dapat disimpulkan bahwa besarnya tingkat akumulasi logam berat merkuri $(\mathrm{Hg})$ tertinggi pada tanaman kacang kalopo (Calopogonium mucunoides) terdapat pada reaktor ke-3 dengan waktu remediasi 50 hari, dan besarnya tingkat akumulasi logam berat merkuri (Hg) sesuai nilai Faktor Biokonsentrasi (BCF) dan Faktor Translokasi berturut-turut adalah 6,74 (BCF $>1)$ dan 0,06 (TF $<1)$ sehingga tanaman kacang kalopo (Calopogonium mucunoides) dapat dikategorikan sebagai salah satu tanaman fitoremediator terhadap tanah tercemar logam berat merkuri $(\mathrm{Hg})$ namun dalam mekanisme fitostabilisasi. 


\section{Daftar Pustaka}

Arisusanti, R. J., dan Purwani, K. I., (2013). Pengaruh Mikoriza Glomus fasciculatum Terhadap Akumulasi Logam Timbal $(\mathrm{Pb})$ pada Tanaman Dahlia pinnata. Jurnal Sains dan Seni Pomits, Vol. 2(2). Hal: 2337-3520.

Arsyad, A. R., Farni, Y., dan Ermadani., (2011). Aplikasi Pupuk Hijau (Calopogonium mucunoides dan Pueraria javanica) Terhadap Air Tanah Tersedia dan Hasil Kedelai. Jurnal Hidrolitan, Vol. 2(1). Hal: 31-39

Chussetijowati, J., Tjahaya, P. I., dan Sukmabuana, P., (2012). Fitoremediasi Radionuklida 134Cs dalam Tanah Menggunakan Tanaman Bayam (Amaranthus sp). Hasil Seminar Nasional ke - 16 Teknologi dan Kesehatan PLTN serta Fasilitas Nuklir. Hal: 282 - 289.

Hardiani, H., Kardiansyah, T., dan Sugesty, S., (2011) "Bioremediasi Logam Timbal (Pb) dalam Tanah Terkontaminasi Limbah Sludge Industri Kertas Proses Deinking”. Jurnal Selulosa Hal: 32-41.

Hidayati, N., Syarif, F., dan Juhaeti, T., (2006). Potensi Centrocema pubescence, Calopogonium mucunoides, dan Micania Cordata dalam Membersihkan Logam Kontaminan pada Limbah Penambangan Emas. Jurnal Biodiversitas., ISSN: 1412-033X. Vol.7(1)., Hal: 4-6

Hidayati, N., (2013). Heavy Metal Hyperaccumulator Plant Physiologi. Jurnal Teknik Lingkungan., Vol. 14(2). Hal: $73-82$

Irsyad., Rismawaty, M. S., dan Musafira. (2014). Translokasi Merkuri pada Daun Tanaman Bayam Duri (Amaranthus spinosus L) dari Tanah Tercemar. Online Journal of Natural Science. Vol. 3(1)., Hal: 817

Juhaeti, T., Syarif, F., dan Hidayati, N., (2005). Inventarisasi Tanaman Potensial untuk Fitoremediasi Lahan dan Air Terdegradasi Penambangan Emas. Jurnal Biodiversitas ISSN: 1412-133X., Vol. 6(1). Hal: 31-33

Juhria, A. M., (2016). Fitoremediasi Logam Berat Merkuri (Hg) pada Tanah dengan Tanaman Celosia plumose (Voss) Burv. Jurnal Biologi Makassar., Vol.1(1). Hal: 1-8

Khalifah, S. N., (2007). Studi Keseimbangan adsorpsi Merkuri (II) pada Biomassa Daun Enceng Gondok (Eichornia crasipes) yang Diimmobilisasi pada Matriks Polisiklat. Skripsi Sarjana Fakultas Sains dan Teknologi Universitas Islam Negeri Malang. Malang.

LPPT-UGM., (2018). Lembar Kerja Kompilasi Data Laboratorium Pengujian -LPPT-UGM RDP/5.10.2/LPPT.Universitas Gadjah Mada Yogyakarta.

Litbang Departemen Pertanian. (2010). Mengenal Calopogonium mucunoides Sumber Pupuk Hijau dan Bahan Organik. Artikel Pertanian Vol. 32(4). Hal: 9-11

Soemirat, J., (2003). Toksikologi Lingkungan. Gadjah Mada University Press. Yogyakarta.

Tindaon, F., (2012). Fitoremediasi Logam Berat Menggunakan Berbagai Jenis Tanaman Sayuran Pada Tanah Mengandung Lumpur Kering Limbah Domestik Kota Medan. Fullpaper Seminar Nasional Universitas HKBP Nommensen. Hal: 1-8

U.S EPA., (2007). Treatmen Technologies for Mercury in Soil, Waste, and Water. Office of Superfund Remediation and Technology Inovation, Washington DC. 20460

Widyati, E., (2011). Potensi Tumbuhan Bawah Sebagai Akumulator Logam Berat untuk Membantu Rehabilitasi Lahan Bekas Tambang. Jurnal Mitra Hutan Tanaman.Vol. 6(2). Hal: 46-56. 